\title{
Soil Solarization and Inoculation with Sulphur Oxidizing Bacteria and Their Effects on Some Soil Properties
}

Hala H Gomah*, Mahmoud SM, El-Rewainy HM and Abdrabou MR

Soil and Water Department, Faculty of Agricultural, Assiut University, Egypt

\begin{abstract}
Two greenhouse pot experiments (clayey and sandy soil) were conducted in order to evaluate the effects of solarization (covering the soil with transparent plastic sheets), inoculation with sulfur oxidizing bacteria SOB (isolated Thiobacillus), addition of filter mud cake FMC (one of the sugar industry wastes, Nagaa Hammady Sugar Factory, Egypt) as a source of organic matter and elemental sulfur on some sand and clay soil properties.

In both soils, the temperature of solarized soil was always higher than the nonsolarized one with an average of $6^{\circ} \mathrm{C}$ at $8: 00$ a.m. and $14^{\circ} \mathrm{C}$ at 4:00 p.m. which resulted in a reduction in organic matter percentage (OM\%). Both FMC and $S$ addition had great effects on increasing soil total soluble salts compared to the increase that resulted from either solarization or SOB inoculation. The effect of elemental sulfur addition on decreasing soil $\mathrm{pH}$ was higher than the other treatments in clay soil, while FMC addition was the most effective treatment in sandy soil. The highest increase in available $S$ was always found when soils were treated with elemental sulfur. Each of the treatments increased the available $\mathrm{P}$ in both soils; however the most effective treatment was $\mathrm{FMC}$ addition. Soluble $\mathrm{Ca}^{+2}+\mathrm{Mg}^{+2}$ and $\mathrm{K}^{+}$were always increased due to each of the treatments. The highest increase in soluble $\mathrm{Na}+$ was due to increasing soil temperature by solarization compared to the other treatments.
\end{abstract}

Keywords: Soil solarization; Sulphur oxidizing bacteria; Soil properties; Greenhouse experiments

\section{Introduction}

The term 'soil solarization' or simply 'solarization' refers to the solar heating of moist soil by covering it with clear plastic sheets during periods of high solar radiation. Soil solarization induced changes in soil physical and chemical properties, such as soil structure [1,2], water potential [3], soil pH and EC [4]. Solarization speeds up the breakdown of organic material in the soil resulting in release of soluble nutrients, such as calcium $\left(\mathrm{Ca}^{+2}\right)$, magnesium $\left(\mathrm{Mg}^{+2}\right)$, potassium $\left(\mathrm{K}^{+}\right)$, and fulvic acid, making them more available to plants [5].

The main reasons for assigning thiobacilli as the dominate role in sulfur oxidation process in soils are: Chemolithotrophic sulfur oxidizing bacteria will oxidize reduced forms of sulfur since this is the only or preferred way of obtaining energy [6]. Sulfur oxidation occurred more rapidly when inoculated sulfur used [7]. However, the oxidation of reduced sulfur in soils usually regarded as a microbial process, although some non-biological oxidation of the elemental does occur [8]. Sulfur oxidation is in fact, a chemical process, where tetrathionate accumulate at $45^{\circ} \mathrm{C}$ in a fertile loam soil, a result suggesting that thermophilic or abiotic oxidation of elemental sulfur to $\mathrm{S}_{4} \mathrm{O}_{6}$ was occurring [6].

The most important factors governing the rate of sulfur oxidation are temperature and water potential [9], variation in particles size [10], manufacturing processes and additives [11], soil fertility [12].

Sulfur oxidation and nutrient availability may increase with the addition of organic matter to sulfur amended soils that contains low amount of organic matter [13]. Soil $\mathrm{pH}$ decreased from 8.1 to 6.7 by the application of WS 90 (wetable S) at a rate of $1000 \mathrm{Kg} \mathrm{S} \mathrm{h}^{-1}$ compared with the control [14]. Sulfur application considerably increased the EC and the soluble sulfate in calcareous soils with little differences between different rates of application [15] showed that. In some calcareous soil, $\mathrm{S}$-application increased the chemically available $\mathrm{P}$ from native soil apatite or added rock phosphate [16], whereas in others it increased available P only when P-fertilizer was added to the soil but soil P was not affected [17]. Our experiment was achieved to indicate the changes of the some soil properties as a result of solarization and/or inoculation with sulfur oxidizing bacteria along with sulfur and filter mud cake addition.

\section{Materials and Methods}

Two greenhouse experiments (clayey soil and sandy soil) were conducted at Soils and Water Department in black polyethylene bags $25-30 \mathrm{~cm}$ high, $20 \mathrm{~cm}$ diameter filled with $5 \mathrm{~kg}$ soil. The soil was irrigated and lifted for 48 hours to reach field capacity then, covered by colorless transparent polyethylene sheets. The soil was kept moist near field capacity across the experiment and water was added as the soil needed. Soil temperature was measured daily at 8:00 a.m. and 4.00 p.m. at $8 \mathrm{~cm}$ depth in nonmulched and mulched soils using soil thermometers. Eight weeks after the termination of solarization period the soil samples were taken with $2.5 \mathrm{~cm}$ diameter soil tube, air-dried and stored in plastic bags for chemical analysis [18].

\section{Isolation of Thiobcillus strain}

The isolate used in the present study is Thiobacillus spp. The Thiobacillus strain was isolated from composite sample of clayey soil of Assiut Experimental Farm which cultivated with faba bean plants. Starkey's medium was used for the isolation and subsequent cultivation have the following composition $\mathrm{NH}_{4} \mathrm{Cl} 0.2 \mathrm{~g}, \mathrm{KH}_{2} \mathrm{PO}_{4} 0.4 \mathrm{~g}, \mathrm{MgCl}_{2} 0.1 \mathrm{~g}$,

*Corresponding author: Hala $\mathrm{H}$ Gomah, Soil and Water Department, Faculty of Agricultural, Assiut University, Egypt 71526, Tel: 00201096955337; Fax: 2331384088(+2); E-mail: Halagomaa71@hotmail.com

Received June 26, 2014; Accepted July 17, 2014; Published July 24, 2014

Citation: Gomah HH, Mahmoud SM, El-Rewainy HM, Abdrabou MR (2014) Soil Solarization and Inoculation with Sulphur Oxidizing Bacteria and Their Effects on Some Soil Properties. J Microbial Biochem Technol S3: 005. doi:10.4172/19485948.S3-005

Copyright: (c) 2014 Gomah HH, et al. This is an open-access article distributed under the terms of the Creative Commons Attribution License, which permits unrestricted use, distribution, and reproduction in any medium, provided the original author and source are credited 
$\mathrm{FeCl}_{2}$ trace, $\mathrm{NaHCO}_{3}, 1.0 \mathrm{~g}$ and $\mathrm{Na}_{2} \mathrm{~S}_{2} \mathrm{O}_{3} 5.0 \mathrm{~g}$ dissolved in $1 \mathrm{~L}$ distil water [19]. The medium was sterilized at 15 pounds pressure for fifteen minutes, the thiosulfate and carbonate were sterilized, separately, and then they were added by means of sterile pipettes. The initial reaction of this medium was about $\mathrm{pH}=8.6$ to 9.6 . Ten grams of soil were added to $200 \mathrm{ml}$ of the sterilized liquid medium in a $250 \mathrm{ml}$ Erlenmeyer flask and shaked on rotary shaker for $1 \mathrm{hr}$ then incubated at $30-34^{\circ} \mathrm{C}$ for 15 days. One $\mathrm{ml}$ aliquots of the suspension was spread on the surface of the Starkey's solid agar medium in Petri plates and the plates were incubated at $30-34^{\circ} \mathrm{C}$ for 10 days. After incubation, the developing Thiobacillus colonies were repeatedly purified by single colony isolation and the purity of the selected isolate was then tested microscopically before studying their characteristics.

Microscopic examination of the isolate grown on Starkey's broth and agar media at age of $24 \mathrm{hrs}$ and 5 day old were made for the determination of cell morphology (gram reaction dimension and motility). Also, colony characteristics (size, form, shape, surface, elevation, consistency, color and edge) were examined on the strain. The composition of broth Starkey's medium, routinely used for growing and testing morphological and physiological characteristics of the isolate e.g., diverse growth temperature requirements of this isolate, determine the optimum growth temperature, capability of use organic substrate (yeast, glucose) and denitrification as follows:

Growth temperature requirements and determining the optimum temperature of Thibacillus spp. isolate: Five sterilized tubs (contained $9 \mathrm{ml}$ of Starkey's liquid medium inoculated with $1 \mathrm{ml}$ of 5 day old isolated culture) were used in this test. The tubes were incubated at $4,25,30,34,45$ and $50^{\circ} \mathrm{C}$. After 5 -days the positive tubes were counted [20].

Using (glucose and yeast extract) by isolated Thiobacillus: Starkey's liquid medium used for this test and modified by adding D-Glucose or Yeast Extract at concentration of $5 \mathrm{~g} / \mathrm{L}$. The glucose and yeast extract prepared at this concentration and sterilized separately then, added by sterilized pipettes. Five sterilized tubs (contained $9 \mathrm{ml}$ of Starkey's glucose or Yeast Extract liquid medium) was inoculated with $1 \mathrm{ml}$ of 5 days old culture of the isolated Thiobacillus, and the tubes were incubated for 5 days at $34^{\circ} \mathrm{C}$, then the positive tubes were counted [20].

Growth curve characteristics: A growth curve was made for Thiobcillus isolate grown on a sterilized $200 \mathrm{ml}$ of Starkey liquid medium dispensed in a $250 \mathrm{ml}$ capacity Erlenmeyer flask (five replicate used with the same preparation medium). The medium was inoculated with $2 \mathrm{ml}$ of 5 days-old culture of the strain, and the inoculated flasks were incubated for 5 days at $30-34^{\circ} \mathrm{C} .10 \mathrm{ml}$ samples of the developing cultures were taken periodically for optical density readings. The optical density was measured at wavelength $600 \mathrm{~nm}$ using Spectronic 20, Bauch and Lomb colorimeter [20].

The experimental design was factorial experiment with four factors arranged as split plots on the basis of Randomized Complete Block Design with four replications. Two levels of solarization (solarization and nonsolarization) were allocated to the main plots, and two levels of filter mud cake (with $2 \%$ filter mud cake and without filter mud cake) were assigned as subplots, two level of elemental sulfur (with 1 ton/ feddan. elemental sulfur and without elemental sulfur) were assigned as sub-subplots, and two levels of inoculation with sulfur-oxidizing bacteria (with inoculation and without inoculation) were assigned as sub-sub-subplots. Bacterial inoculums were prepared as Starkey's liquid inoculums contained $10^{9}$ viable cells $/ \mathrm{ml}$, determined on plates of Starke's agar medium). Supper phosphate fertilizer was added to the hole unites of all the experiments at a rate of 1 ton/feddan in pots and laboratory experiments and $500 \mathrm{~kg} /$ feddan at field experiment.

The clay soil had a clayey texture $(48,29$ and $23 \%$ clay, silt and sand) with $2.5 \% \mathrm{CaCO}_{3}, 1.3 \mathrm{dS} \mathrm{m}{ }^{-1} \mathrm{EC}(1: 1), 7.6 \mathrm{pH}$ (1:1 suspension) and $1.3 \% \mathrm{OM}$. Whereas the sandy soil had a sandy texture $(3,8$ and $89 \%$ clay, silt and sand, respectively) with $15.2 \% \mathrm{CaCO}_{3}, 1.7 \mathrm{dS} \mathrm{m}^{-1}$ EC (1:1), $8.3 \mathrm{pH}$ (1:1 suspension) and 0.5\% OM. The used Filter Mud Cake (FMC) contained $70.74 \%$ organic matter, $\mathrm{pH}$ (1:10 suspension) 6.75, EC (at $25^{\circ} \mathrm{C}$ and $1: 10$ extract) $4.00 \mathrm{ds} / \mathrm{m}$, total phosphorus $\left(\mathrm{P}_{2} \mathrm{O}_{5}\right)$ $1.78 \%$, total potassium $\left(\mathrm{K}_{2} \mathrm{O}\right) 0.47 \%$, total sodium $\left(\mathrm{Na}_{2} \mathrm{O}\right) 0.16 \%$, total calcium $(\mathrm{CaO}) 0.94 \%$, total magnesium $(\mathrm{MgO}) 0.12 \%$, total sulfur $(\mathrm{S})$ $2.95 \%$, total Fe 169.6 ppm, total Mn 297.0 ppm, total Zn 259.3 ppm and total Cu $196.9 \mathrm{ppm}$.

Total soluble salts were measured in 1:1 soil extracts by the electric conductivity method (EC) [21]. Calcium and magnesium were titrated by versene [22], while sodium and potassium were measured by flamephotometere [21]. Organic matter content was determined using Walkely-Black method, following [22]. Soil pH was measured in a 1:1 (soil:water) suspensions using a glass electrode [21]. Available Phosphorus was determined calorimetrically using the chlorostanous phosphomolybdic acid method according to [21]. Available sulfur in soil samples was extracted using $500 \mathrm{ppm} \mathrm{P}$ of $\mathrm{KH}_{2} \mathrm{PO}_{4}$. Also, sulfur was determined in soil extracts and FMC digests by turbidity method. Soil texture was carried out using the pipette method [23].

\section{Results and Discussion}

\section{Morphological, cultural characteristics and growth curve of isolated Thiobacillus strain:}

Results of the tested morphological and cultural characteristics of Thiobacillus isolated strain show that cells shape were small, gramnegative, single rods, $0.5-4.0 \mu \mathrm{m}$ in length and $0.5^{-1}$ in diameter, produce no spores and non-motile. Tables 1 and 2, respectively, indicate some cultural characteristics and the physiological characteristic determined for the isolated Thiobacillus strain in comparison to known Thiobacillus species.

Cultural characteristics of the isolate Thiobacillus strain indicate that on agar thiosulfate+glucose medium the isolate produce circular, convex, yellow and viscoid colonies $1-3 \mathrm{~mm}$ in diameter with entire edge. Whereas, in the thiosulfate agar medium without glucose the colonies color was white and its size was $0.5-0.7 \mathrm{~mm}$ in diameter but with the same other previous characteristics (in the thiosulfate+glucose agar medium) (Table 1).

The physiological characteristics of the isolate Thiobacillus strain in comparison to known Thiobacillus species according to [24,25] indicate

\begin{tabular}{|l|c|c|}
\hline Colony characteristic & Thiosulfate medium+glucose & Thiosulfate medium \\
\hline Form & Circular & circular \\
\hline Shape & convex & convex \\
\hline Surface & smooth & smooth \\
\hline Elevation & raised & raised \\
\hline Size & $1-3 \mathrm{~mm}$ & $0.5-0.7 \mathrm{~mm}$ \\
\hline Color & yellow & white \\
\hline Consistency & viscoide & viscoide \\
\hline Edge & entire & entire \\
\hline
\end{tabular}

Table 1: Cultural characteristic of isolated Thiobacillus strain on Thiosulfate medium with or without glucose. 


\section{Test \\ Motility}

Formation of surface pellicle of sulfur particle on thiosulfate medium

Growth as chemolithotroph

Anaerobic growth and denitrification with thiosulfate

Growth on nutrient agar

Growth on thiosulfate agar

Mixotrophic growth with thiosulfate +glucose

Mixotrophic growth with thiosulfate + yeast extract

Autotrophic growth with sulfur

Optimum temperature

Optimum $\mathrm{Ph}$

Final $\mathrm{pH}$ when grown on thiosulfate medium

Proposed species

\begin{tabular}{|c|c|c|c|c|}
\hline Isolated Thiobacillus & T.nonellus & T.versutus & T.delicatus & T.thioparus \\
\hline- & - & + & - & + \\
\hline+ & + & - & + & + \\
\hline- & - & - & - & + \\
\hline+ & - & - & + & - \\
\hline+ & + & + & - & - \\
\hline+ & + & + & + & + \\
\hline+ & + & + & + & - \\
\hline- & + & - & + & - \\
\hline 30 & - & - & $30-35$ & + \\
\hline 7 & $25-30$ & $7.5-7.9$ & $5.5-6.0$ & $6.5-7.2$ \\
\hline 5 & $7.5-7.9$ & $5.8-6.5$ & $2.5-3.5$ & $3.5-4.0$ \\
\hline
\end{tabular}

Table 2: Physiological Characteristic determined the isolated Thiobacillus strain in comparison to known Thiobacillus species (Bergy's 1989).

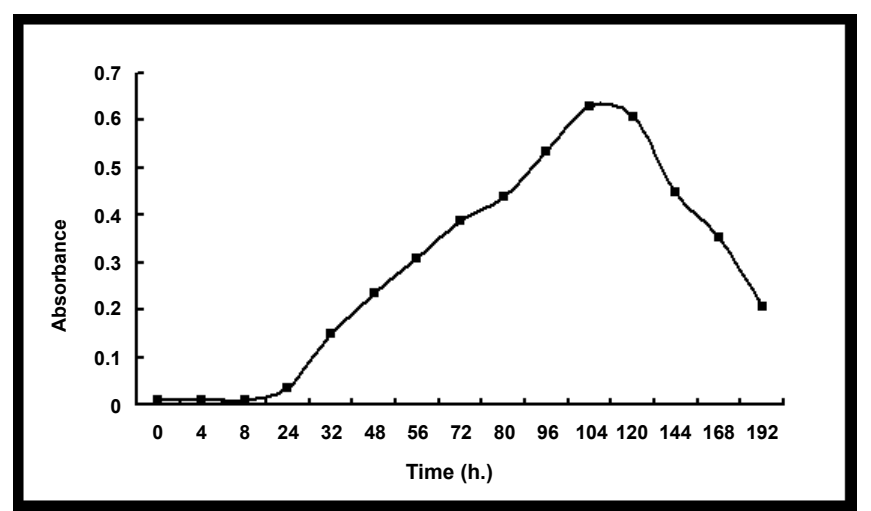

Figure 1: Growth curve of isolated Thiobacillus strain grown on Starkey's liquid medium.

that there are four speices of Thiobacillus are too closely to our isolate. These speices are T. thioparus, T. dilicatus, T. versutus, T. novellus.

T. thioparus is strictly chemolithotroph and autotrophic bacteria. The lowest $\mathrm{pH}$ produced aerobically in thiosulfate medium is 3.5-4.0. $T$. delicatus can grow anaerobically and the lowest $\mathrm{pH}$ produce in thiosulfate medium is $2.5-3.5$. T. versutus had ability to motile by means of polar flagella and do not form surface pellicle of sulfur particles. The lowest $\mathrm{pH}$ produced in thiosulfate medium is 5.8-6.5. T. novellus can grow mixotrophically on thiosulfate+glucose medium, it is facultative chemolithotrophic bacteria, the final $\mathrm{pH}$ when grown on thiosulfate medium is 5.0-5.5, cannot grown anaerobically, nonmotile and it can form a pellicle of sulfur particles on thiosulfate medium. Though, according to these physiological characteristics we can say that the proposal spices of the present isolate is T. novellus where the present isolate have the same characteristics of Thiobacillus novellus (Table 2).

The growth curve, drawn for Thiobacillus isolated strain in Starkey's liquid medium is shown in Figure 1. Optical density was measured, by Spectrophotometer where the turbidity is related to both the cell numbers and the sulfur particles that produce with the growth of bacteria. Therefore, both the numbers of cells and the amount of sulfur particles could be used as a function for growth of bacteria. A lag phase of $24 \mathrm{hrs}$ was recorded for the isolated strain, after which cell numbers increased exponentially with the time. As indicated from the measurement of optical density of Starkey's liquid media, the maximum total growth for the strains occurred after $104 \mathrm{hrs}$ from inoculation.

\section{Effect of solarization on soil temperature}

Curves in Figure 2 show that the weekly mean of temperature in both covered soils were generally greater than those in uncovered soils with an average of 6 and $14^{\circ} \mathrm{C}$ at 8:00 a.m. and 4:00 p.m., respectively, overall the experimental period. After the fifth week, which always recorded the lowest temperatures, gradual increase in the temperature was recorded in all cases. The temperature was fluctuating due to the fluctuation of the ambient air temperature. These finding are in accordance with those reported by $[24,25]$.

\section{Effect of solarization, FMC and S application, and inoculation with sulfur-oxidizing bacteria on some soil properties}

Main effect: Data in Tables 3 and 4 summarize the main effects of solarization, application of Filter Mud Cake (FMC), elemental sulfur (S) and inoculation with Sulfur-Oxidizing Bacteria (SOB) on some properties of clay and sandy soils, respectively. Data show the noticeable significant effects of solarization, $S$ and FMC addition on most of the discussed soil parameters. Data indicate that solarization of clay soil caused a highly significant reduction in soil organic matter percentage by about $23 \%$ and $30 \%$ in clay and sandy soils, respectively, compared to that of nonsolarized treatments. This was due to the increase of soil temperature which was higher in sandy soil than in clay soil and resulted in rapid decomposition of organic matter. The most obvious result was the significant increase in soil organic matter content by about $73 \%$ (from $1.21 \%$ to $2.09 \%$ ) and $213 \%$ (from $0.3 \%$ to $0.94 \%$ ) in clay (Table 3) and sandy soil (Table 4), respectively, received FMC over the untreated soil. While the addition of sulfur decreased OM content in sandy soil by $10.6 \%$, it had no effect in clay soil. The inoculation with SOB almost had no effect on soil OM decomposition in both soils.

Data also indicate that solarization, $S$ and FMC addition significantly increased the EC in both soils. The increase of EC in clay soil was 16, 55 and $33 \%$ while in sandy soil it was 20,29 and $45 \%$ for solarization, S and FMC treatments over the untreated soil, respectively.

Soil $\mathrm{pH}$ was significantly decreased by all the discussed treatments and in both soils as appear in Tables 3 and 4 . All treatments resulted in a highly significant increase in extractable $S$ having the highest increase in soil treated with elemental S (75\% and 78\% increase in clay and sandy soil, respectively, compared to the untreated soil). While solarization, FMC and SOB increased the soil S by 24,45 and $24 \%$ in clay soil and 39, 60 and 30\% in sandy soil, respectively, compared with the untreated soils. 

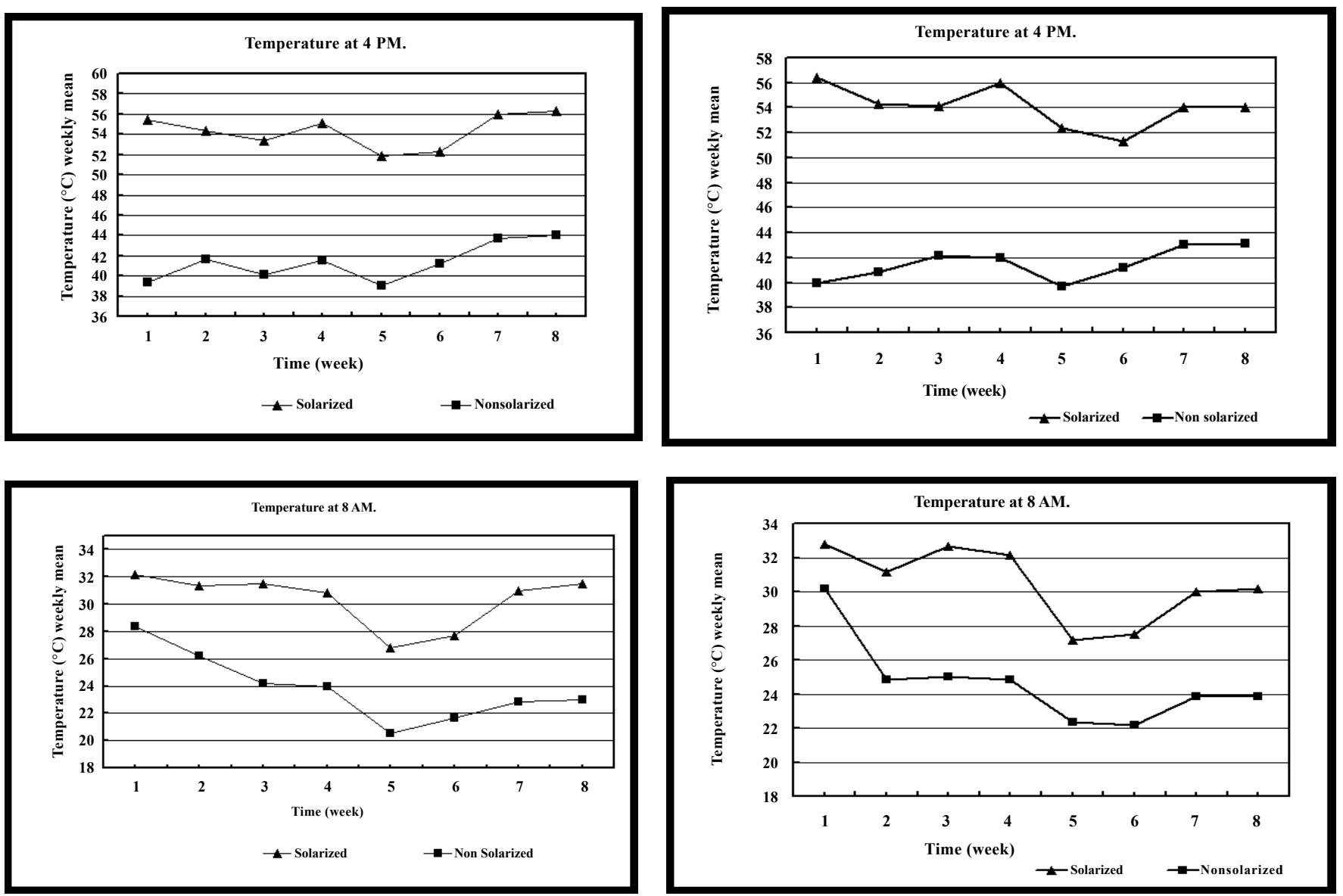

Figure 2: Soil temperature in solarized and nonsolarized clay and sandy soils (at 8:00 a.m. and 4:00 p.m.).

\begin{tabular}{|c|c|c|c|c|c|c|c|c|}
\hline \multirow[t]{2}{*}{ Treatment } & \multirow[t]{2}{*}{ OM (\%) } & \multirow[t]{2}{*}{$\mathrm{EC}(\mathrm{ds} / \mathrm{cm})$} & \multirow[t]{2}{*}{$\mathrm{pH}$} & \multirow{2}{*}{$\begin{array}{c}\text { Available S } \\
\text { (ppm) }\end{array}$} & \multirow{2}{*}{$\begin{array}{c}\text { Available P } \\
\text { (ppm) }\end{array}$} & \multicolumn{3}{|c|}{ Soluble cations (meq/100 g soil) } \\
\hline & & & & & & $\mathrm{Ca}^{+2}+\mathrm{Mg}^{+2}$ & $\mathrm{Na}^{+}$ & $\mathbf{K}^{+}$ \\
\hline NonSolarized & 1.86 & 9.47 & 7.69 & 531 & 69.4 & 13.65 & 1.39 & 0.038 \\
\hline Solarized & $1.44^{\star *}$ & $10.95^{*}$ & $7.61^{* *}$ & $656^{* *}$ & $90.88^{* *}$ & $18.63^{\star \star}$ & $2.01^{\star *}$ & $0.048^{* *}$ \\
\hline - FMC & 1.21 & 8.76 & 7.66 & 485 & 64.43 & 12.72 & 1.71 & 0.037 \\
\hline$+\mathrm{FMC}$ & $2.09^{* *}$ & 11.66 & $7.63^{*}$ & $702^{* *}$ & $95.86^{* *}$ & $19.56^{* *}$ & 1.69 & $0.049^{* *}$ \\
\hline$-S$ & 1.68 & 8 & 7.72 & 431 & 75.5 & 9.77 & 1.58 & 0.039 \\
\hline$+S$ & 1.62 & $12.42^{* *}$ & $7.58^{* *}$ & $756^{* *}$ & $84.78^{* *}$ & $22.51^{* *}$ & $1.82^{* *}$ & $0.047^{* *}$ \\
\hline Umino & 1.59 & 10.02 & 7.67 & 530 & 72.26 & 16 & 1.63 & 0.041 \\
\hline Ino & 1.72 & 10.39 & $7.63^{* *}$ & $657^{\star *}$ & $88.02^{* \star}$ & 16.28 & $1.77^{\star \star}$ & 0.045 \\
\hline
\end{tabular}

$\mathrm{FMC}=$ Filter Mud Cake, $\mathrm{S}=$ granuled elemental sulfur, Ino=inoculation with Sulfur-Oxidizing Bacteria $(\mathrm{SOB}), \mathrm{EC}=\mathrm{ds} / \mathrm{m}$ at $25^{\circ} \mathrm{C} 1: 1 \mathrm{soil}$ extract, $\mathrm{pH}=1: 1 \mathrm{soil}$ suspension, * $=$ significant $(P<0.05)^{* *}=$ high significant $(p<0.01)$.

Table 3: Main effects of solarization, FMC and S addition, and inoculation with SOB on some properties of clay soil.

Phosphorus availability was significantly increased by all treatments. The most effective treatment was FMC which increased available $\mathrm{P}$ to reach 95.86 and $81.61 \mathrm{ppm}$ with an increase of 49 and $72 \%$ in clay and sandy soils, respectively. Application of sulfur and inoculation with S-oxidizing bacteria caused a noticeable effect on $\mathrm{NaHCO}_{3}$-extractable phosphorus but the amount of available $\mathrm{P}$ in these treatments were less than the amount found with FMC and solarization treatments in both soils. Soluble $\mathrm{Ca}^{+2}+\mathrm{Mg}^{+2}$ were significantly increased by solarization, FMC and $\mathrm{S}$ addition in both soils as shown in Tables 3 and 4 where it reached $22.51 \mathrm{meq} / 100 \mathrm{~g}$ soil with $\mathrm{S}$ addition to clay soil and 6.48 $\mathrm{meq} / 100 \mathrm{~g}$ with FMC addition to sandy soil. While the inoculation with SOB had no significant effects in both soils. Increases in soluble mineral nutrients including $\mathrm{NH}_{4}, \mathrm{NO}_{3}$, Phosphorus, $\mathrm{K}^{+}, \mathrm{Ca}^{+2}, \mathrm{Mg}^{+2}$, $\mathrm{Mn}^{+2}, \mathrm{Fe}^{+3}, \mathrm{Cl}^{-}$and $\mathrm{Cu}^{+2}$ have been detected in solarized soils in several studies [26] although sometimes inconsistently [27-29], especially for the minor elements [4,30].

Soil solarization was the most effective treatment in increasing soluble $\mathrm{Na}^{+}$in both soils, where it reached 2.01 and $5.05 \mathrm{meq} / 100 \mathrm{~g}$ in clay and sandy soils, respectively. Soluble $\mathrm{K}^{+}$was significantly increased in both soils under all treatments except SOB inoculation with almost the same value.

\section{Interaction Effects}

Clay soil: The interaction effects of solarization, application of 


\begin{tabular}{|c|c|c|c|c|c|c|c|c|}
\hline \multirow[t]{2}{*}{ Treatment } & \multirow[t]{2}{*}{ OM (\%) } & \multirow[t]{2}{*}{$\mathrm{EC}(\mathrm{ds} / \mathrm{cm})$} & \multirow[t]{2}{*}{$\mathrm{pH}(1: 1)$} & \multirow{2}{*}{$\begin{array}{c}\text { Available S } \\
\text { (ppm) }\end{array}$} & \multirow{2}{*}{$\begin{array}{c}\text { Available P } \\
\text { (ppm) }\end{array}$} & \multicolumn{3}{|c|}{ Soluble cations (meq/100 g soil) } \\
\hline & & & & & & $\mathrm{Ca}^{+2}+\mathrm{Mg}^{+2}$ & $\mathrm{Na}^{+}$ & $\mathbf{K}^{+}$ \\
\hline No solarized & 0.73 & 5.91 & 7.49 & 503 & 56.54 & 5.08 & 2.73 & 0.187 \\
\hline Solarized & $0.51^{* *}$ & $7.12^{* *}$ & $7.32^{* *}$ & $700^{* *}$ & $72.56^{* *}$ & $6.38^{* *}$ & $5.05^{\star *}$ & $0.281^{*}$ \\
\hline$-F M C$ & 0.3 & 5.25 & 7.5 & 463 & 47.48 & 4.99 & 4.45 & 0.192 \\
\hline$+\mathrm{FMC}$ & $0.94^{\star *}$ & $7.63^{\star *}$ & $7.31^{* *}$ & $740^{* *}$ & $81.61^{* *}$ & $6.48^{* *}$ & $3.33^{* *}$ & $0.276^{\star *}$ \\
\hline$-S$ & 0.66 & 5.62 & 7.5 & 433 & 57.69 & 5.16 & 3.46 & 0.217 \\
\hline$+S$ & $0.59^{* *}$ & $7.25^{\star \star}$ & $7.32^{* *}$ & $770^{* *}$ & $71.41^{* *}$ & $6.31^{* \star}$ & $4.32^{\star *}$ & $0.251^{*}$ \\
\hline Unino & 0.62 & 5.76 & 7.41 & 524 & 57.86 & 5.7 & 3.78 & 0.227 \\
\hline Ino & 0.62 & $6.96^{\star *}$ & 7.4 & $680^{* *}$ & $71.23^{* *}$ & 5.76 & 4.01 & 0.241 \\
\hline
\end{tabular}

Table 4: Main effects of solarization, FMC and $S$ application, and inoculation with SOB on some properties of sandy soil. FMC=Filter Mud Cake, $S=$ granuled elemental sulfur, Ino=inoculation with sulfur-oxidizing bacteria $(\mathrm{SOB}), \mathrm{EC}=\mathrm{ds} / \mathrm{m}$ at $25^{\circ} \mathrm{C} 1: 1$ soil extract, $\mathrm{pH}=1: 1$ soil suspension, ${ }^{*}=\operatorname{significant}(\mathrm{P}<0.05){ }^{* *}=\mathrm{high}$ significant $(\mathrm{p}<0.01)$.

\begin{tabular}{|c|c|c|c|c|c|c|c|c|c|}
\hline \multicolumn{2}{|l|}{ Treatment } & \multirow{2}{*}{$\begin{array}{c}\text { OM (\%) } \\
1.3\end{array}$} & \multirow{2}{*}{$\begin{array}{c}\mathrm{EC}(\mathrm{ds} / \mathrm{cm}) \\
7.83\end{array}$} & \multirow{2}{*}{$\begin{array}{c}\text { pH 1:1 } \\
7.72 \\
\end{array}$} & \multirow{2}{*}{$\begin{array}{c}\begin{array}{c}\text { Available S } \\
\text { (ppm) }\end{array} \\
404\end{array}$} & \multirow{2}{*}{$\begin{array}{c}\text { Available P } \\
\text { (ppm) } \\
54.67\end{array}$} & \multicolumn{3}{|c|}{ Soluble cations (meq/100 g soil) } \\
\hline Noncolarizod & -FMC & & & & & & $\begin{array}{c}\mathbf{C a}^{+2}+\mathbf{M g}^{+2} \\
11.15\end{array}$ & $\begin{array}{c}\mathrm{Na}^{+} \\
1.4\end{array}$ & $\begin{array}{c}\mathbf{K}^{+} \\
0.033\end{array}$ \\
\hline ivutisudarizau & $+F M C$ & 2.41 & 11.1 & 7.66 & 659 & 84.13 & 16.14 & 1.37 & 0.043 \\
\hline \multirow{2}{*}{ solarized } & -FMC & 1.13 & 9.69 & 7.6 & 566 & 74.18 & 14.29 & 2.02 & 0.041 \\
\hline & $+\mathrm{FMC}$ & 1.76 & 12.21 & 7.61 & 745 & 107.58 & 22.98 & 2.01 & 0.053 \\
\hline \multicolumn{2}{|l|}{ LSD 1\% } & 0.17 & 0.47 & 0.04 & 44 & NS & 0.79 & NS & NS \\
\hline \multirow{2}{*}{ Nonsolarizad } & $-S$ & 1.9 & 8.68 & 7.76 & 430 & 66.81 & 9.24 & 1.26 & 0.036 \\
\hline & $+S$ & 1.81 & 10.25 & 7.62 & 633 & 71.99 & 18.06 & 1.51 & 0.041 \\
\hline \multirow{2}{*}{ solarized } & $-S$ & 1.34 & 7.31 & 7.68 & 432 & 84.2 & 10.3 & 1.9 & 0.042 \\
\hline & $+S$ & 1.55 & 14.59 & 7.53 & 880 & 97.57 & 26.96 & 2.13 & 0.052 \\
\hline \multicolumn{2}{|l|}{ LSD $1 \%$} & NS & NS & NS & 37 & 4.07 & 0.68 & NS & NS \\
\hline \multirow{2}{*}{ Nonsolarizad } & Unino & 1.69 & 8.94 & 7.7 & 468 & 61.66 & 13.67 & 1.35 & 0.036 \\
\hline & Ino & 2.02 & 9.99 & 7.67 & 595 & 77.14 & 13.63 & 1.43 & 0.04 \\
\hline \multirow{2}{*}{ solarized } & Unino & 1.48 & 11.11 & 7.63 & 593 & 82.87 & 18.34 & 1.91 & 0.046 \\
\hline & Ino & 1.41 & 10.8 & 7.58 & 719 & 98.9 & 18.93 & 2.12 & 0.048 \\
\hline \multicolumn{2}{|l|}{ LSD 1\% } & NS & 0.26 & NS & NS & NS & NS & NS & NS \\
\hline
\end{tabular}

Table 5: The interaction effects of solarization, FMC and $S$ addition, and inoculation with $\mathrm{SOB}$ on some soil properties, clay soil. $\mathrm{FMC}=$ filter mud cake, $\mathrm{S}=\mathrm{granuled}$ elemental sulfur, Ino=inoculation with sulfur-oxidizing bacteria $(\mathrm{SOB}), \mathrm{EC}=\mathrm{ds} / \mathrm{m}$ at $25^{\circ} \mathrm{C} 1: 1$ soil extract, $\mathrm{pH}=1: 1$ soil suspension.

\begin{tabular}{|c|c|c|c|c|c|c|c|c|c|}
\hline \multirow{2}{*}{\multicolumn{2}{|c|}{ Treatment }} & \multirow{3}{*}{$\begin{array}{c}\text { OM (\%) } \\
1.17\end{array}$} & \multirow{3}{*}{$\begin{array}{c}\mathrm{EC}(\mathrm{ds} / \mathrm{cm}) \\
6.3\end{array}$} & \multirow{3}{*}{$\begin{array}{c}\text { pH 1:1 } \\
7.72\end{array}$} & \multirow{3}{*}{$\begin{array}{c}\begin{array}{c}\text { Available S } \\
\text { (ppm) }\end{array} \\
333\end{array}$} & \multirow{3}{*}{$\begin{array}{c}\text { Available P } \\
\text { (ppm) } \\
56.68\end{array}$} & \multicolumn{3}{|c|}{ Solable cations (meq/100 g soil) } \\
\hline & & & & & & & \multirow{2}{*}{$\begin{array}{c}\mathbf{C a}^{+2}+\mathbf{M g}^{+2} \\
6.13\end{array}$} & \multirow{2}{*}{$\begin{array}{r}\mathrm{Na}^{+} \\
1.5\end{array}$} & \multirow{2}{*}{$\begin{array}{c}\mathbf{K}^{+} \\
0.034\end{array}$} \\
\hline -FMC & $-S$ & & & & & & & & \\
\hline & $+S$ & 1.26 & 11.22 & 7.6 & 637 & 72.18 & 19.31 & 1.92 & 0.04 \\
\hline \multirow[t]{2}{*}{$+F M C$} & $-S$ & 2.11 & 9.69 & 7.71 & 529 & 94.33 & 13.41 & 1.66 & 0.043 \\
\hline & $+S$ & 2.07 & 13.63 & 7.55 & 876 & 97.38 & 25.71 & 1.72 & 0.053 \\
\hline \multicolumn{2}{|c|}{ LSD $1 \%$} & NS & 0.56 & 0.03 & 37 & 4.07 & NS & 0.14 & NS \\
\hline \multirow{2}{*}{-FMC } & Unino & 1.16 & 8.63 & 7.66 & 398 & 58.74 & 12.54 & 1.63 & 0.037 \\
\hline & Ino & 1.27 & 8.89 & 7.66 & 572 & 70.11 & 12.9 & 1.79 & 0.038 \\
\hline \multirow{2}{*}{$+F M C$} & Unino & 2.01 & 11.42 & 7.67 & 662 & 85.78 & 19.47 & 1.64 & 0.045 \\
\hline & Ino & 2.16 & 11.89 & 7.59 & 742 & 105.93 & 19.65 & 1.75 & 0.051 \\
\hline \multicolumn{2}{|c|}{ LSD 1\% } & NS & 0.26 & 0.04 & 25 & 3.26 & NS & NS & NS \\
\hline \multirow{2}{*}{$-S$} & Unino & 1.57 & 7.9 & 7.74 & 361 & 66.33 & 9.56 & 1.48 & 0.039 \\
\hline & Ino & 1.67 & 8.09 & 7.69 & 501 & 84.68 & 9.98 & 1.68 & 0.039 \\
\hline \multirow{2}{*}{$+S$} & Unino & 1.6 & 12.15 & 7.59 & 700 & 78.2 & 22.45 & 1.78 & 0.043 \\
\hline & Ino & 1.76 & 12.69 & 7.56 & 813 & 91.36 & 22.57 & 1.86 & 0.049 \\
\hline \multicolumn{2}{|c|}{ LSD 1\% } & NS & NS & NS & NS & 3.26 & NS & NS & NS \\
\hline
\end{tabular}

Table 6: The interaction effects of application of FMC, elemental sulfur, and inoculation with SOB on some properties of clay soil. $\mathrm{FMC}=$ filter mud cake, S=granuled elemental sulfur, Ino=inoculation with sulfur-oxidizing bacteria ( $\mathrm{SOB}$ ), $\mathrm{EC}=\mathrm{ds} / \mathrm{m}$ at $25^{\circ} \mathrm{C} 1: 1$ soil extract, $\mathrm{pH}=1: 1$ soil suspension.

FMC and elemental sulfur, and inculcation with SOB on some clay soil properties is shown in Tables 5 and 6 . Although the application of FMC to solarized soil caused a significant effect on increasing soil organic matter percentage up to $1.76 \%$, the increase of OM percentage was much higher by $63 \%$ in the nonsolarized soil received the same FMC rate Table 5. Which indicate that solarization decreases the effect of OM addition. Though, solarized soil contained higher EC than the nonsolarized ones, the addition of FMC to any of the soils resulted in more increase in the EC. Which lead to the result that the highest
EC value was found when solarization was combined with FMC addition to the soil. Soil $\mathrm{pH}$ was significantly decreased as a result of the interaction between solarization and addition of FMC compared with the unsolarized soil without FMC addition. Available sulfates and phosphate as well as soluble $\mathrm{Ca}^{+2}+\mathrm{Mg}^{+2}$ in the soil recorded the highest values in solarized soil amended with FMC.

Solarized soil received elemental sulfur contained less O.M in comparison with nonsolarized soil treated with elemental sulfur, while 


\begin{tabular}{|c|c|c|c|c|c|c|c|c|c|}
\hline & & & & & Available S & Available P & Solub & on (me & oil) \\
\hline Treatment & & OM (\%) & $\mathrm{EC}(\mathrm{ds} / \mathbf{c m})$ & $\mathrm{pH}$ & (ppm) & (ppm) & $\mathrm{Ca}^{+2}+\mathrm{Mg}^{+2}$ & $\mathrm{Na}^{+}$ & $\mathrm{K}^{+}$ \\
\hline $\mathrm{NeClarized}$ & -FMC & 0.38 & 4.55 & 7.59 & 373 & 27.79 & 4.34 & 3.22 & 0.153 \\
\hline Nosolarızed & +FMC & 1.08 & 7.28 & 7.4 & 633 & 85.3 & 5.81 & 2.24 & 0.221 \\
\hline Colorizod & -FMC & 0.22 & 5.94 & 7.41 & 553 & 67.18 & 5.63 & 5.69 & 0.232 \\
\hline solarized & +FMC & 0.81 & 7.98 & 7.22 & 848 & 77.93 & 7.14 & 4.42 & 0.331 \\
\hline LSD $1 \%$ & & NS & 0.12 & NS & 15 & 2.71 & NS & NS & NS \\
\hline $\mathrm{NeSOlarized}$ & $-S$ & 0.76 & 4.97 & 7.51 & 295 & 53.53 & 4.38 & 2.1 & 0.17 \\
\hline NoSolarızed. & $+S$ & 0.71 & 6.85 & 7.48 & 711 & 59.55 & 5.78 & 3.37 & 0.203 \\
\hline Colorizod & $-S$ & 0.56 & 6.27 & 7.48 & 572 & 61.85 & 5.93 & 4.83 & 0.265 \\
\hline solarızed & $+S$ & 0.45 & 7.66 & 7.16 & 829 & 83.26 & 6.84 & 5.28 & 0.298 \\
\hline LSD $1 \%$ & & NS & 0.19 & 0.11 & 11 & 3.01 & 0.3 & NS & NS \\
\hline $\mathrm{NeColorizod}$ & Unino & 0.77 & 5.11 & 7.51 & 453 & 52.47 & 5.04 & 2.7 & 0.176 \\
\hline Nosolarized & Ino & 0.7 & 6.71 & 7.48 & 553 & 60.61 & 5.12 & 2.76 & 0.197 \\
\hline Colarized & Unino & 0.48 & 6.4 & 7.32 & 595 & 63.26 & 6.36 & 4.86 & 0.278 \\
\hline Solarızed & Ino & 0.54 & 7.53 & 7.32 & 806 & 81.85 & 6.41 & 5.25 & 0.284 \\
\hline LSD $1 \%$ & & NS & 0.14 & NS & 11 & 3.11 & NS & NS & NS \\
\hline
\end{tabular}

Table 7: The interaction effects of solarization, FMC and S application, and inoculation with SOB on some properties of sandy soil. FMC=Filter Mud Cake, S=granuled elemental sulfur, Ino=inoculation with sulfur-oxidizing bacteria ( $\mathrm{SOB}$ ), $\mathrm{EC}=\mathrm{ds} / \mathrm{m}$ at $25^{\circ} \mathrm{C} 1: 1$ soil extract, $\mathrm{pH}=1: 1$ soil suspension.

\begin{tabular}{|c|c|c|c|c|c|c|c|c|c|}
\hline \multirow{2}{*}{\multicolumn{2}{|c|}{ Treatment }} & \multirow{3}{*}{$\begin{array}{c}\text { OM (\%) } \\
0.34\end{array}$} & \multirow{3}{*}{$\begin{array}{c}\text { EC (ds/m) } \\
4.48\end{array}$} & \multirow{3}{*}{\begin{tabular}{|l|}
$\mathbf{P H}$ \\
7.54
\end{tabular}} & \multirow{3}{*}{$\begin{array}{c}\begin{array}{c}\text { Available S } \\
\text { (ppm) }\end{array} \\
322\end{array}$} & \multirow{3}{*}{$\begin{array}{c}\text { Available P } \\
\text { (ppm) } \\
41.9\end{array}$} & \multicolumn{3}{|c|}{ Soluble cation (meq/100 g soil) } \\
\hline & & & & & & & \multirow{2}{*}{$\begin{array}{c}\mathbf{C a}^{+2}+\mathbf{M g}^{+2} \\
4.02\end{array}$} & \multirow{2}{*}{$\begin{array}{l}\mathrm{Na}^{+} \\
3.84\end{array}$} & \multirow{2}{*}{$\begin{array}{c}\mathbf{K}^{+} \\
0.187\end{array}$} \\
\hline FMO & $-S$ & & & & & & & & \\
\hline -FIVIC & $+S$ & 0.26 & 6.01 & 7.47 & 604 & 53.07 & 6.01 & 5.07 & 0.197 \\
\hline \multirow{2}{*}{$+\mathrm{FMC}$} & $-S$ & 0.98 & 6.76 & 7.45 & 545 & 73.48 & 6.15 & 3.09 & 0.247 \\
\hline & $+S$ & 0.91 & 8.51 & 7.17 & 936 & 89.75 & 6.86 & 3.58 & 0.304 \\
\hline \multicolumn{2}{|c|}{ LSD 1\% } & NS & NS & 0.11 & 11 & 3.01 & 0.33 & NS & NS \\
\hline \multirow{2}{*}{-FMC } & Unino & 0.31 & 4.47 & 7.48 & 377 & 42.13 & 4.65 & 4.2 & 0.19 \\
\hline & Ino & 0.29 & 6.02 & 7.52 & 549 & 52.84 & 5.38 & 4.71 & 0.194 \\
\hline \multirow{2}{*}{ +FMC } & Unino & 0.93 & 7.04 & 7.34 & 670 & 73.6 & 5.92 & 3.36 & 0.264 \\
\hline & Ino & 0.95 & 8.22 & 7.28 & 810 & 89.63 & 7.09 & 3.31 & 0.287 \\
\hline \multicolumn{2}{|c|}{ LSD 1\% } & NS & 0.14 & NS & 11 & 3.11 & 0.35 & NS & NS \\
\hline \multirow{2}{*}{$-S$} & Unino & 0.67 & 5.12 & 7.5 & 363 & 51.12 & 4.41 & 3.41 & 0.215 \\
\hline & Ino & 0.64 & 6.12 & 7.49 & 504 & 64.26 & 5.76 & 3.51 & 0.22 \\
\hline \multirow{2}{*}{$+S$} & Unino & 0.57 & 6.39 & 7.33 & 685 & 64.61 & 6.16 & 4.15 & 0.239 \\
\hline & Ino & 0.6 & 8.12 & 7.31 & 855 & 78.21 & 6.71 & 4.5 & 0.262 \\
\hline \multicolumn{2}{|c|}{ LSD $1 \%$} & NS & 0.14 & NS & 11 & NS & NS & NS & NS \\
\hline
\end{tabular}

Table 8: The interaction effects of application of FMC, S, and inoculation with $\mathrm{SOB}$ on some sandy soil properties. FMC=Filter Mud Cake, S=granuled elemental sulfur Ino=inoculation with Sulfur-Oxidizing Bacteria (SOB), $E C=d s / m$ at $25^{\circ} \mathrm{C} 1: 1$ soil extract, $\mathrm{pH}=1: 1$ soil suspension.

it contained more OM when compared with solarized soil without $\mathrm{S}$ addition. Mulching soil surface with clear plastic sheets resulted in significant increase in EC, available sulfates, available phosphates and soluble cations $\left(\mathrm{Ca}^{+2}+\mathrm{Mg}^{+2}, \mathrm{Na}^{+}\right.$and $\left.\mathrm{K}^{+}\right)$in soil treated with elemental sulfur compared with the soils unsolarized or solarized. Which means that solarization enhanced the effect of $\mathrm{S}$ on decreasing the $\mathrm{pH}$ and thus increasing the soluble and extractable nutrients.

Addition of FMC to the soil received elemental sulfur led to great increase in soil EC, available sulfates, phosphates, and soluble $\mathrm{Ca}^{+2}$ $+\mathrm{Mg}^{+2}$ compared to soil received no FMC with or without sulfur addition (Table 6). The addition of $S$ with or without FMC also increased these values. These facts lead to the enhancement effect of both FMC and S on each other when added together. On the other hand, OM increased by the addition of FMC but not $S$ addition, which led to no significant effect of $S$ on soils with or without FMC addition. The same effect was found in the soils treated with or without FMC and SOB. These results are in agreement with those reported by $[31,32]$.

As in all $\mathrm{S}$ treatments, $\mathrm{pH}$ always decrease with the addition of $\mathrm{S}$, and this decrease become even more with the addition of FMC. The same effect on $\mathrm{pH}$ values were found with $\mathrm{SOB}$ treatments combined with either FMC or S treatments (Table 6). Inoculation with SOB, ether with FMC or $S$ treatments, had significant effect on increasing of $S, P$, $\mathrm{Na}^{+}$content and accordingly EC too. This is because of the effect of these bacteria on oxidizing $\mathrm{S}$ in soil, which causes the increase of EC. That effect of SOB was enhanced by the application of either FMC or S. On the other hand, the increase in $\mathrm{OM}, \mathrm{Ca}^{+2}+\mathrm{Mg}^{+2}$ and $\mathrm{K}^{+}$content were mainly referred to the addition of FMC and not SOB. While $\mathrm{S}$ addition accompanied with $\mathrm{SOB}$ resulted in a significant increase in $\mathrm{Ca}^{+2}+\mathrm{Mg}^{+2}$ and $\mathrm{K}^{+}$content.

Sandy soil: Data in Table 7 represent the interaction effects of solarization accompanied with applications of either FMC or elemental sulfur or inoculation with SOB on some properties of sandy soil in pot experiment. Solarization of soil amended with FMC for 8 weeks resulted in significant reduction in soil organic matter content compared with the nonsolarized soil. The same treatment exhibited the highest significant increase in $\mathrm{EC}$ values and the lowest value of $\mathrm{pH}$, in comparison with all other treatments. This may be due to the fact that solarization of soil was accompanied with the acceleration of organic matter decomposition which resulted in release of organic acids which in turn reduce soil $\mathrm{pH}$ (or increase soil acidity) and increases the solubility of salts. 
Data in Table 7 also indicate that both extractable sulfates and soluble cation were increased significantly by solarization of soil with and without FMC treatments. The increase was also found with FMC treatment with or without solarization except for $\mathrm{Na}^{+}$which decreased, but not significantly, with the addition of FMC. Solarization of soil without FMC treatment caused obvious increase in extractable $\mathrm{P}$, the same effect occurred due to the addition of FMC either with or without solarization. However, solarizing the soil treated with FMC decreased the amount of extractable $\mathrm{P}$, which matches the percentage of OM [33].

Solarization of soil always had the same significant effect on decreasing organic matter and $\mathrm{pH}$ while increasing EC, S, P and soluble cations when it was combined with either S or SOB treatments. While $\mathrm{S}$ addition had highly significant effect on decreasing the $\mathrm{pH}$ and on increasing the EC, extractable $\mathrm{S}$, extractable $\mathrm{P}$ and soluble cations either with or without solarization. On the other hand, SOB had significant effect on increasing extractable S, P and accordingly EC.

Data in Table 8 summarized the interaction effects of the application of FMC and elemental sulfur, and inoculation with SOB of sandy soil in pot experiment on some soil prosperities. Addition of FMC at a rate of $2 \%$ to the sandy soil amended or not amended with sulfur significantly increased OM percentage in the soil compared to those found in soil received no FMC or elemental sulfur. Similar trend was found in regard to Electrical Conductivity (EC). Addition of FMC alongside with sulfur to the soil led to obvious decrease in soil $\mathrm{pH}$ from 7.45 to 7.17 (Table 8), this mean that adding elemental sulfur to the soil may be the main reason of reducing soil $\mathrm{pH}$ rather than adding FMC. Application of FMC to sulfur amended or un-amended soil led to highly significant increases in both available sulfates and phosphate. Similarly, the concentration of $\mathrm{Ca}^{+2}+\mathrm{Mg}^{+2}$ and $\mathrm{K}^{+}$in soil extract were greater in soil amended with FMC and sulfur than the un-amended one.

Application of FMC to inoculated or uninoculated soil increased OM percentage and EC in soil. It was noticeable that the application of FMC to inoculated soil scored the lowest value of soil $\mathrm{pH}$. Both available sulfates and phosphates values were greater in soil amended with FMC and inoculated with SOB (Table 8). Soluble $\mathrm{Ca}^{+2}+\mathrm{Mg}^{+2}$ and $\mathrm{K}^{+}$concentrations reached their highest values in FMC amended soil inoculated with SOB [34].

Though the effect of FMC addition in the presents of either $\mathrm{S}$ or $\mathrm{SOB}$, was very clear on decreasing $\mathrm{pH}$ and increasing $\mathrm{OM}, \mathrm{EC}, \mathrm{S}, \mathrm{P}, \mathrm{K}^{+}$ and $\mathrm{Ca}^{+2}+\mathrm{Mg}^{+2}$, the effect of either $\mathrm{S}$ or $\mathrm{SOB}$ was found on increasing EC, $\mathrm{S}, \mathrm{P}, \mathrm{K}^{+}$, and $\mathrm{Ca}^{+2}+\mathrm{Mg}^{+2}$ but not on OM. Which indicate that the maximum values found for these parameters were because of the interaction effect between FMC either with S or with SOB. On the contrary, both FMC and $\mathrm{S}$ decreased soil $\mathrm{pH}$ and thus, their interaction had the highest effect on decreasing $\mathrm{pH}$ value to reach 7.17 while it reached 7.28 with the addition of FMC+ SOB.

The interaction between $\mathrm{S}$ addition and SOB inoculation resulted in significant increase of $\mathrm{EC}, \mathrm{S}$ and $\mathrm{Ca}^{+2}+\mathrm{Mg}^{+2}$ which made the values of these parameters were the highest among the other treatments. On the other hand, the significant increase in $\mathrm{Na}^{+}$and the decrease in $\mathrm{pH}$ may be attributed only to $\mathrm{S}$ addition and not to $\mathrm{SOB}$ inoculation as shown in Table 8.

\section{Conclusion}

Increasing the soil temperature due to solarization resulted in a reduction in OM percentage, while the addition of $S$ had less effect and the incubation of SOB almost had no effect. Both FMC and S addition had great effects on increasing soil EC compared to the increase that resulted from either solarization or SOB inoculation. The effect of elemental sulfur addition on decreasing soil $\mathrm{pH}$ was higher than the other treatments in all clay experiments, while FMC addition was the most effective treatment in sandy soil experiments. Each of the treatments increased the available $\mathrm{P}$ in all experiments; however the most effective treatment was FMC addition. Soluble $\mathrm{Ca}^{+2}+\mathrm{Mg}^{+2}$ and $\mathrm{K}^{+}$were always increasing due to each of the treatments. The highest increase in soluble $\mathrm{Na}^{+}$was due to increasing soil temperature either by solarization or simulation compared to the other treatments [35].

\section{References}

1. Katan J and DeVay JE (1991) Soil Solarization. Boca Raton: CRC Press.

2. Thuriés L, Larre-Larrouy MC, Feller C (2000) Influences of organic fertilization and Solarization in a greenhouse on particle size fractions of a Mediterranean sandy soil. Biol Fertile soils 32: 449-457.

3. Zak DR, Homes WE, Mac Donald NW, Pregitzer KS (1999) Soil temperature matric potential and the kinetics of microbial respiration and nitrogen mineralization. Soil Sci Soc Am J 63: 575-584.

4. Grunzweig JM, Katan J, Ben-Tal Y, Rabinowitch HD (1999) The role of minera nutrients in the increased growth response of tomato plants in solarized soil. Plant and Soil 206: 21- 27.

5. Ahmed Y, Hameed A, Eslam M (1996) Effect of soil solarization on corn stalk rot. Plant and soil 179: 17-24.

6. Wainwright M (1984) Sulfur oxidation in soils. Adv Agron 37: 349-396.

7. García de la Fuente R, Carrión C, Botella S, Fornes F, Noguera V, et al. (2007) Biological oxidation of elemental sulfur added to three composts from different feedstocks to reduce their $\mathrm{pH}$ for horticultural purposes. Bioresour Technol 98: 3561-3569

8. Wainwright $M$ and Killharn K (1980) Sulfur oxidation by fusarium solani. Soil Biol Biochem 12: 555-558.

9. Sholeh RD, Lefroy B, Blair GJ (1997) Effect of nutrients and elemental sulfur partical size on elemental sulfur oxidation and the growth of thiobacillus thiooxidans. Aust J Agric Res 48: 497-501.

10. Laishely EJ, Bryant RD, Kobryn BW, Hyne JB (1986) Microcrystalline structure and surface area of elemental sulfur as factors influencing its oxidation by thiobacilluse albertis. Can J Microbiol 32: 237-242.

11. Lindemann WC, Alburto JJ, Haffner WM, Bono AA (1991) Effect of sulfur source on sulfur oxidation. Soil Sci Soc Am J 55: 85-90.

12. Nor YM and Tabatabai MA (1977) Oxidation of elemental sulfur in soils. Soil Sc Soc Am J 41: 736-741.

13. Cifuentes FR, Lindeman WC (1993) Organic matter stimulation of elemental sulfur oxidation on a calcareous soil. Soil Sci Soc Am J 57: 727-731.

14. Slaton NA, Norman RJ, Gilmour JT (2001) Oxidation rates of commercial elemental sulfur products applied to an alkaline silt loam from Arkansas. Soil Sci Soc Am J 65: 239-243.

15. Modaihsh AS, Al-Mostafa WA, Metwally Al (1989) Effect of elemental sulfur on chemical changes and nutrient availability in calcareous soils. Plant and soil 116: 95-101.

16. Garcia ME, Carloni L (1977) The effect of sulfur on the solubility and forms of phosphorus in soil. Agrochemica 21: 163-169.

17. Gubta VR, Mehla IS (1980) Influence of sulfur on the yield and concentration of $\mathrm{Cu}, \mathrm{Mn}, \mathrm{Fe}$, and $\mathrm{Mo}$ in bersseem (Trifolium alexandrium) grown on two different soils. Plant and soil 56: 229-234.

18. Chen Y, Katan J, Gamliel A, Aviad T (2000) Involvement of soluble organic matter in increases plant growth in solarized soils. Biol Fertil Soil 32: 28-34.

19. Starkey RL (1935) Isolation of some bacteria which oxidize thiosulfate. Soil Sci 39: 197-219.

20. Cappuccino JT, Sherman N (1996) Microbiology, Laboratory Manual. 4thed. pp: 115-128 USA.

21. Jackson ML (1973) Soil chemical analysis. Prentice-Hall, Inc., Englewood Cliffs. NJ, USA. 
Citation: Gomah HH, Mahmoud SM, El-Rewainy HM, Abdrabou MR (2014) Soil Solarization and Inoculation with Sulphur Oxidizing Bacteria and Their Effects on Some Soil Properties. J Microbial Biochem Technol S3: 005. doi:10.4172/1948-5948.S3-005

Page 8 of 8

22. Baruah TC, Barthakur HP (1997) A Textbook of soil analysis. Vikas Publishing House PVT LTD, New Delhi, India.

23. Piper CS (1950) Soil and Plant Analysis. 1st. ed. Intrescience Public., New York

24. Streck NA, Schneider FM, Buriol GA (1996) Soil heating by solarization inside plastic greenhouse in Santa Maria, Rio Grande do Sule. Brazil Agricultural and forest Meteorology 82: 73-82

25. Gelsomino A, Cacco G (2006) Compositional shifts of bacterial groups in a solarized and amended soil as determined by denaturing gradient gel electrophorsis. Soil Biology and Biochemistry. 38: 91-102.

26. Chen Y, Gamliel A, Stapleton JJ, Aviad T (1991) Chemical, physical, and microbial changes related to plant growth in disinfested soils, in Soil solarization (J. Katan and J. E. DeVay, Eds.). CRC Press, Boca Raton, Florida. 103-129.

27. Daelemans A (1989) Soil solarization in West-Cameroon: effect on weed control, some chemical properties and pathogens of the soil, in III international symposium on soil disinfestations (Vanachter, A., Ed.). Acta Horticulturae 255:169-175.

28. Moura MLR and Palminha J (1994) A non-chemical method for the control of Pyrenochaeta lycopersici of tomato in the north of Portugal, in II Symposium on protected cultivation of solanacea in mild winter climates, Adana, Turkey (Cockshull, K.E., and Y. Tüzel). Acta Horticuturae 366: 317-322.
29. Coates-Beckford PL, Cohen JE, Ogle LR, Prendergast CH, Riley DM (1998) Mulching soil to increase yield and manage plant parasitic nematodes in cucumber (Cucumis sativus L.) fields: influence of season and plant thickness. Nematropica 28: 81-93.

30. Stapleton JJ (1998) Modes of action of solarization and biofumigation, in Soil solarization and integrated management of soil pests: proceedings of the second conference on soil solarization, Aleppo, Syria (Stapleton, J. J., J. E. DeVay, and C. L. Elmore, Eds.). FAO plant production and protection paper 147: 78-88.

31. Curtin D, Beare MH, McCallum FM (2007) Sulfur in soil and light fraction organic matter as influenced by long-term application of super phosphate. Soil Biology \& Biochemistry 39: 2547-2554.

32. Bergey's (1989) Manual of Systematic Bacteriology. ed .N .R. Kriey and J. G. Holt. vol. I, pp. 1842-1858. Williams and Wilkins, Baltimore, london.

33. Jackson ML (1967) Soil chemical analysis. Prentice-Hall, Inc., Englewood Cliffs, New Jersey, U.S.A.

34. Lawrence JR, Germida JJ (1991) Enumeration of sulfur-oxidizing-populations in Saskatchewan agriculture soils. Can J Soil Sci 71: 127-136.

35. Page AL, Miller RH, Keeney DR (1984) Methods of Soil Analysis. Part2Chemical and Microbiological Properties. 2ed., USA. pp: 815-830.
This article was originally published in a special issue, Bacteria: Biochemical Physiology handled by Editor. Prof. Cheorl-Ho KIM, Sungkyunkwan University, Korea 